\title{
Desapropriação para megaeventos no Rio de Janeiro: INTERESSE PÚBLICO DE QUEM?
}

\author{
Expropriation for mega-events in the city of Rio de Janeiro: \\ public interest of whom?
}

\section{Larissa Oliveira}

Professora Assistente de Direito Administrativo da Universidade Federal do Rio de Janeiro (UFRJ). Bacharel em Direito e Mestre em Teoria do Estado e Direito Constitucional pela Pontifícia Universidade Católica do Rio de Janeiro (PUC/RJ). Aluna do programa de Pós-Graduação Stricto Sensu em Direito (Direito Administrativo) da Universidade de São Paulo (USP). E-mail: larissapdeoliveira@gmail.com.

\section{Úrsula Vasconcellos}

Estudante de Direito da Universidade Federal do Rio de Janeiro (UFRJ). Monitora bolsista da disciplina de Direito Administrativo e integrante do Grupo de Pesquisa em Direito Administrativo (GPDA) da mesma Universidade. E-mail: ursula.vasconcellos@gmail.com.

\section{Pedro Araujo}

Estudante de Direito da Universidade Federal do Rio de Janeiro (UFRJ). Monitor bolsista da disciplina de Direito Administrativo e integrante do Grupo de Pesquisa em Direito Administrativo (GPDA) da mesma Universidade. E-mail: pedrofedericiaraujo@gmail.com.

Felipe Silva

Estudante de Direito da Universidade Federal do Rio de Janeiro (UFRJ). Monitor bolsista da disciplina de Direito Tributário e integrante do Grupo de Pesquisa em Direito Administrativo da mesma Universidade. E-mail: felipeteixeiraf@yahoo.com.br.

\section{JeISON OLIVEIRA}

Estudante de Direito da Universidade Federal do Rio de Janeiro (UFRJ) e integrante do Grupo de Pesquisa em Direito Administrativo da mesma Universidade. E-mail: jeisonbra@gmail.com. 
Natasha Ribeiro

Estudante de Direito da Universidade Federal do Rio de Janeiro (UFRJ) e integrante do Grupo de Pesquisa em Direito Administrativo da mesma Universidade. E-mail: nat_mand@hotmail.com.

Tayná Chagas

Estudante de Direito da Universidade Federal do Rio de Janeiro (UFRJ). Monitora bolsista da disciplina de Direito Administrativo e integrante do Grupo de Pesquisa em Direito Administrativo (GPDA) da mesma Universidade. E-mail: taynatavares.ufrj@gmail.com.

\section{Carolina Barros}

Estudante de Direito da Universidade Federal do Rio de Janeiro (UFRJ) e integrante do Grupo de Pesquisa em Direito Administrativo da mesma Universidade. E-mail: carolina.geissler@gmail.com.

\section{Resumo}

O Rio de Janeiro já vivencia a rotina de sede dos megaeventos. Assim, no intuito de promover políticas públicas, o Estado imprime intervenções para obras de infraestrutura. Nesta linha, a desapropriação ganha espaço enquanto ato/procedimento de direito público utilizado pelo Estado para apropriar-se do bem de terceiro, com fundamento no interesse social ou utilidade pública, de forma que esse terceiro pode entender-se prejudicado. Soma-se a preocupação com os reflexos imediatos na realidade social e nos direitos fundamentais, apresentando-se a contextualização e a justificativa da presente pesquisa. O objetivo é verificar o interesse público nessas desapropriações. Para tanto, foram estabelecidas duas vertentes de pesquisa relacionadas aos momentos práticos da desapropriação: (i) a verificação dos Decretos municipais para desapropriação; e (ii) a análise de ações judiciais. No que tange ao primeiro item, trabalha-se com a hipótese de que o Poder Executivo não aprofunda a análise do interesse público na desapropriação. Quanto ao segundo item, busca-se analisar o acesso ao Judiciário pelo desapropriado para contestar o mérito da desapropriação. Em paralelo, são estudados os conceitos de interesse público, o mérito, a discricionariedade, bem como a motivação dos atos administrativos, à luz do Direito-Administrativo Constitucional.

Palavras-chave: Desapropriação. Interesse público. Discricionariedade. 


\begin{abstract}
Rio de Janeiro faces the routine of a city that will host mega-events. Therefore, in order to implement public policies, the city goes through a variety of interventions led by public authorities. In such scenario, expropriations gain bigger proportions as a mechanism utilized by the government for taking of individual's property rights, on the grounds of social interest and public utility, in a way that such individuals may deem themselves injured. This study contemplates the concern regarding the immediate reflections of such governmental interventions on social reality and fundamental rights. The aim is to verify the public interest in such expropriations. For such achievement, this study analyses: (i) the expropriation decrees occurred in the city of Rio de Janeiro; and (ii) Brazil's superior courts' decisions. In relation to the first topic, the hypothesis is that public authorities do not analyze the public interest in the expropriations. In relation to the second item, the aim is to verify the access of individuals who had their property rights seized to the courts to contest the expropriation itself. The concepts of public interest, merit, discretion and motivation of administrative acts, in light of the Administrative-Constitutional Law, are worked in parallel.
\end{abstract}

Keywords: Expropriation. Public interest. Discretion.

SumÁRIO: Introdução. 1. Desapropriação: conceito e fundamentos. 2. A problemática do interesse público na desapropriação. 3. A questão da motivação. 4. Decretos expropriatórios. 5. Discricionariedade e mérito. 6. Pesquisa jurisprudencial. Conclusão. Referências.

\title{
INTRODUÇão
}

A cidade do Rio de Janeiro hospedará os dois maiores eventos esportivos mundiais: a Copa do Mundo de 2014 e as Olimpíadas de 2016. Dentro do contexto de realização desses megaeventos esportivos se insere a produção deste trabalho, que trata de uma perspectiva macro do instituto da desapropriação, utilizando da interlocução entre o estudo do Direito Administrativo e a prática urbanística governamental imposta pelas obras necessárias ao melhoramento das cidades-sede.

A problematização se coloca dentro dos fundamentos da desapropriação, principalmente na tensão que se estabelece entre os direitos individuais e a estrutura social que reveste, ou deveria revestir, o procedimento expropriatório. Refere-se à expressão e presença do interesse público nos dois polos da desapropriação, a fun- 
ção social da propriedade e o direito de propriedade em seu caráter patrimonial. Nesse cenário complexo de garantias e direitos do cidadão justapostos à necessidade de atuação da Administração Pública, surge grande preocupação jurídica e social, evidenciada pelo Relatório do Conselho de Direitos Humanos da Organização das Nações Unidas ${ }^{246}$ sobre as remoções em cidades que hospedaram megaeventos. $\mathrm{O}$ volume de desapropriações que os comitês organizadores desses eventos exigem pode ensejar um descuido do instituto da desapropriação, sob a roupagem de um conceito desvirtuado de interesse público, fadado a lesar os direitos humanos e a comprometer a ordem constitucional.

$\mathrm{O}$ artigo desenvolve um estudo teórico jurídico sobre a desapropriação e como esse instituto do Direito Administrativo reflete, influencia e repercute na prática do poder administrativo e no dia-a-dia de uma sociedade complexa. A noção jurídica do interesse público e a sua aplicação no âmbito dos decretos expropriatórios e das ações judiciais de desapropriação consubstancia o objeto desta pesquisa. Para tanto, foram determinados três objetivos específicos: (i) analisar a publicização e a compreensão da motivação do ato de desapropriação, em especial, a expressão do interesse público na conduta administrativa; (ii) verificar a atuação do Poder Judiciário na análise do mérito da desapropriação, isto é, se o juiz discute o interesse público em desapropriar, evidenciado pelos requisitos constitucionais da desapropriação, quais sejam, a utilidade pública e o interesse social; e (iii) se o cidadão desapropriado possui mecanismos eficazes para contestar, suspender ou mesmo anular a desapropriação.

Parte-se de uma perspectiva doutrinária crítica sobre a desapropriação e o interesse público, dentro de uma nova lógica jurídica permeada por um movimento constitucionalista social e democrático pós Constituição de 1988, para construir a hipótese a ser comprovada: a utilização da desapropriação para viabilizar os megaeventos na cidade do Rio de Janeiro e sua regulamentação no ordenamento jurídico brasileiro estão em descompasso com uma ordem constitucional de direitos e garantias fundamentais, que não aceita a posição exclusivamente verticalizada do Estado, mas coloca o interesse público a serviço de todos, da sociedade e do cidadão como membro dessa ordem comunitária.

Para trabalhar os aspectos conceituais jurídicos serão utilizadas como referenciais teóricos os conceitos de interesse público, mérito, discricionariedade e motivação nas obras dos professores Celso Antônio Bandeira de Mello e Maria Sylvia Zanella Di Pietro. São conceitos que guardam toda a complexidade da prática administrativa da desapropriação e da possibilidade de levar as questões pertinentes à apreciação do Poder Judiciário. O interesse público, como já mencionado, será trabalhado como conceito dinâmico e mutável, que varia de acordo com a noção de Estado. A discricionariedade e o mérito administrativo serão discutidos no espaço

246 Ver http://daccess-dds-ny.un.org/doc/UNDOC/GEN/G09/176/13/PDF/G0917613.pdf?OpenElement. Acessado em: 01.08.2013. 
concedido pelo legislador ao administrador para decidir diante do caso concreto, um juízo de oportunidade e conveniência típico do titular do Poder Executivo, um poder de escolha política. Por sua vez, a motivação é tratada como dever de qualquer órgão estatal dentro do paradigma contemporâneo do Direito Administrativo, mas a noção a ser discutida consubstancia a necessidade de uma amplificação ou não desse dever de justificação da conduta estatal.

A metodologia do trabalho foi construída ao longo da pesquisa e discussão sobre o Direito Administrativo, escolhendo-se o tema da desapropriação em virtude da atualidade do debate e pela contraposição entre necessidades da coletividade e do indivíduo. A noção de interesse público apareceu como conceito jurídico que reflete em todos os problemas que surgem durante os procedimentos de desapropriação. Para verificar, na prática, se há ou não o interesse público na desapropriação para os megaeventos, foi feita uma pesquisa dos decretos expropriatórios municipais, com recorte temporal de três anos e oito meses, tendo por base a data da escolha do Brasil como sede desses megaeventos esportivos ${ }^{247}$, com a intenção de aferir se há motivação ou não do interesse público na desapropriação nesses atos administrativos. Em seguida, surgiu a necessidade de uma pesquisa jurisprudencial para traçar o comportamento do Poder Judiciário em relação às ações judiciais de desapropriação. Foram verificadas todas as decisões disponíveis na base de dados virtual do Supremo Tribunal Federal (STF) e do Superior Tribunal de Justiça (STJ), utilizando-se de palavras-chave para refinamento da pesquisa e verificando o teor das decisões para compreender a conduta do juiz ao analisar o interesse público na desapropriação.

A larga discussão doutrinária e as pesquisas de dados apontam para o anacronismo do Decreto-Lei n. 3.365/1941, que regulamenta a desapropriação. Será demonstrado que a lógica da prática administrativa e judiciária sobre a desapropriação está em descompasso com a ordem constitucional atual. Uma lógica que não respeita o princípio da motivação dos atos administrativos, que impossibilita uma discussão sobre a existência ou não de um interesse público legitimador da atuação do Estado em desapropriar e que, sobretudo, não fornece mecanismos eficazes para que o cidadão desapropriado conteste a desapropriação.

Diante das conclusões e resultados que serão apresentados, algumas sugestões e reflexões sobre a temática podem apontar para a necessidade de se estabelecerem mecanismos que possibilitem a reformulação do instituto da desapropriação como instrumento de política pública social, garantindo assim uma harmônica existência desse tão importante instituto do Direito Administrativo e da nova ordem constitucional pós 1988 .

${ }^{247}$ Ano estimado de início das obras de infraestrutura urbanística necessárias à adequação da cidade do Rio de Janeiro para recebimento das Olimpíadas. Toma-se como marco inicial a divulgação de que a cidade seria sede dos XXXI Jogos Olímpicos de Verão 2016, em 02 de outubro de 2009. Ver http://www.olympic.org/rio-2016-summer-olympics. Acessado em: 20.10.2013. 


\section{DesapropriaÇão: CONCEITO E FUNDAMENTOS}

A desapropriação é ato/procedimento pelo qual o Poder Público, com base no interesse social ou na utilidade pública, de forma compulsória, em caráter originário, toma para si o bem de um particular mediante prévia e justa indenização em dinheiro ${ }^{248-249}$.

O ordenamento jurídico abarca a desapropriação de diversas formas e nos mais variados diplomas legais, sendo a regra fundamental do instituto o art. 5o, XXIV da Constituição ${ }^{250}$. Na presente pesquisa, trabalharemos apenas com a desapropriação ordinária, por utilidade pública ou interesse social, para tanto, o diploma legal pertinente é o Decreto-Lei n. $3.365 / 1941$, considerado como a lei geral das desapropriações.

O referido art. 5ํㅡ. XXIV da CRFB/88 traz os pressupostos da desapropriação, isto é, os requisitos constitucionais que legitimam a atuação da Administração Pública para desapropriar. No intuito didático, expomos as considerações acerca dos pressupostos da desapropriação: a necessidade pública se dá quando a Administração Pública se depara com problema inadiável, cuja única solução é desapropriar o bem de um particular; a noção de utilidade pública é mais ampla, de forma que darse-á quando a desapropriação for vantajosa e conveniente ao interesse coletivo, sem

${ }^{248}$ MELLO, Celso Antônio Bandeira de. Curso de Direito Administrativo. São Paulo: Malheiros, 2010, p. 872.

${ }^{249}$ De certa forma a doutrina do Direito Administrativo traz conceitos bem semelhantes sobre o instituto, vejamos: CARVALHO FILHO, José dos Santos. Manual de Direito Administrativo. Rio de Janeiro: Lumen Juris, 2011, p. 750: "Desapropriação é o procedimento de direito público pelo qual o Poder Público transfere para si a propriedade de terceiro, por razões de utilidade pública ou de interesse social, normalmente mediante o pagamento de indenização.”; DI PIETRO, Maria Sylvia Zanella. Direito Administrativo. São Paulo: Atlas, 2013, pp. 165-166: “A desapropriação é o procedimento administrativo pelo qual o Poder Público ou seus delegados, mediante prévia declaração de necessidade pública, utilidade pública ou interesse social, impõe ao proprietário a perda de um bem substituindo-o em seu patrimônio por justa indenização." Ou ainda: MOREIRA NETO, Diogo de Figueiredo. Curso de Direito Administrativo: Parte Introdutória; Parte Geral; Parte Especial. Rio de Janeiro: Forense, 2006, p. 379: “(...) o grau máximo da intervenção ordinatória e concreta do Estado na propriedade privada, que opera a transferência compulsória de um bem para o domínio público, de forma onerosa, permanente, não executória e de execução delegável, imposta discricionariamente pela declaração de existência de um motivo de interesse público legalmente suficiente."

${ }^{250}$ CRFB/88: "Art. 5o Todos são iguais perante a lei, sem distinção de qualquer natureza, garantindo-se aos brasileiros e aos estrangeiros residentes no País a inviolabilidade do direito à vida, à liberdade, à igualdade, à segurança e à propriedade, nos termos seguintes: (...) XXIV - a lei estabelecerá o procedimento para desapropriação por necessidade ou utilidade pública, ou por interesse social, mediante justa e prévia indenização em dinheiro, ressalvados os casos previstos nesta Constituição;" 
que reflita, necessariamente, um problema emergencial; já o interesse social, deve consubstanciar-se nos próprios direitos sociais, utilizando o instituto da desapropriação em prol dos menos favorecidos e/ou como forma de distribuição de riqueza. ${ }^{251}$

Existem duas fases no transcorrer da desapropriação: a primeira fase é administrativa, na qual há a declaração da utilidade pública ou interesse social do bem a ser desapropriado por meio de ato do chefe do Poder Executivo, em específico, um decreto. ${ }^{252}$ Após, tem início o procedimento de desapropriação, quando o proprietário é notificado de que seu patrimônio será objeto de intervenção drástica do Estado, podendo contestar o ato/procedimento na esfera administrativa. Havendo um acordo entre proprietário e Ente Público, encerra-se aí o procedimento, quando o bem do particular passará a integrar o patrimônio público, após justa indenização. Porém, é cediço que a maioria dos casos de desapropriação não se encerra na fase administrativa, isto porque, quando não há acordo, deverá ser proposta uma ação de desapropriação ${ }^{253}$ pelo Ente expropriante no Poder Judiciário.

O que traz certo desconforto é a impossibilidade de se discutir os pressupostos, o próprio interesse público em desapropriar, dentro do âmbito dessas ações de desapropriação, nas quais só poderá ser debatida a indenização, ou seja, o quantum debeatur pela tomada da propriedade. O regulamento da desapropriação traz a necessidade de uma ação direta para contestar a desapropriação ${ }^{254}$, esta que não é definida em qualquer lugar no ordenamento jurídico. Ou seja, não há propriamente um meio definido para contestar as ações do Poder Público que se utiliza da desapropriação, ou, se há, este meio pode não ser eficaz numa lógica que privilegia o Administrador, de forma que, manter o bem sob o qual pendeu declaração de utilidade pública ou interesse social, será tarefa árdua, quase impossível, conforme se demonstrará a seguir.

Ainda na temática da desapropriação, é importante consignar que o interesse público que expressa seus requisitos/pressupostos encontrará dificuldade ao enfrentar os fundamentos da desapropriação. Isto porque, dentro da fundamentação do instituto da desapropriação está a função social da propriedade, conceito largamente aceito na ordem constitucional atual que relativiza o direito de propriedade,

\footnotetext{
${ }^{251}$ DI PIETRO, Maria Sylvia Zanella. Direito Administrativo. São Paulo: Atlas, 2013. p. 176.

${ }^{252}$ A lógica do ato administrativo expropriatório também será abordada em item específico neste estudo, onde suas peculiaridades e características serão desenvolvidas.

${ }^{253}$ Torna-se necessário estabelecer como padrão que todas as vezes em que se mencionar a ação de desapropriação, estar-se-á falando nesta ação específica proposta pelo Poder Público em face do proprietário, após sua discordância no procedimentos administrativo da desapropriação.

${ }^{254}$ Isto em virtude do arts. 9o e 20 do Decreto-Lei n.o 3.365/1941: Art. 9o Ao Poder Judiciário é vedado, no processo de desapropriação, decidir se se verificam ou não os casos de utilidade pública. (...) Art. 20. A contestação só poderá versar sobre vício do processo judicial ou impugnação do preço; qualquer outra questão deverá ser decidida por ação direta.
} 
condicionando seu exercício ao atendimento da sua função social ${ }^{255}$. Entretanto, é certo que se estabelece uma tensão entre a função social da propriedade e o direito de propriedade em seu caráter privado, que, por mais que condicionado ao exercício funcional, ainda está erigido como direito fundamental. ${ }^{256}$

Deste arcabouço lógico-conceitual, no decorrer do trabalho, uma perspectiva crítica será traçada sobre este tão importante instituto do Direito Administrativo que é a desapropriação. Uma proposta de democratizar o instituto e de destacar o seu caráter social que não se restringirá à lógica legalista de discussão e contestação da desapropriação, que impede qualquer debate relacionado ao mérito da desapropriação, despolitizando o tratamento da questão ${ }^{257}$. É certo que há necessidade de um entendimento da desapropriação como procedimento sujeito a uma espécie de controle de gestão democrática, o que torna a definição do interesse público tema crucial para o desenvolvimento do estudo.

\section{A PRoblemática do interesse público na deSAPropriaÇÃo}

A possibilidade de o Poder Público efetivar a desapropriação suscita o debate acerca da supremacia do interesse público sobre o particular. A problemática, conquanto recorrente na academia brasileira, revela-se tema ainda inesgotado e pressupõe a incursão na própria noção de interesse público, seus limites e significação. Notadamente se considerarmos que nem sempre o interesse das partes é adverso ao interesse do todo e nem sempre que o Estado alega interesse público há efetivamente interesse público.

A rigor, a expressão não apresenta conceituação uniforme, manifestando dificuldade, escassez de consenso. Interesse público é noção polissêmica, permeada de acentuada carga valorativa. $\mathrm{O}$ que não representa novidade, porquanto reflexo de uma realidade social cambiante, permissiva de larga mobilidade de sentido. Assim é que o interesse público se depara com a mutabilidade própria das relações da contemporaneidade.

Não obstante, uma das críticas lançadas à primazia do interesse público sobre o particular diz respeito exatamente a sua indeterminabilidade abstrata ${ }^{258}$. Ques-

${ }^{255}$ LIMA, Adriana Nogueira Vieira, MACEDO FILHO, Edson. Desapropriação em áreas urbanas de assentamentos informais: limites e alternativas a sua aplicação. In. Revisitando o instituto da desapropriação (Coords. Edésio Fernandes e Betânia Alfonsin) Belo Horizonte: Forum, 2009, pp. 225-226.

${ }^{256}$ CRFB/88: "Art. $5^{\circ}$ Todos são iguais perante a lei, sem distinção de qualquer natureza, garantindo-se aos brasileiros e aos estrangeiros residentes no País a inviolabilidade do direito à vida, à liberdade, à igualdade, à segurança e à propriedade, nos termos seguintes: (...) XXIII - a propriedade atenderá a sua função social; (...)"

${ }^{257}$ FERNANDES, Edésio, AFONSIN, Betânia. Revisitando o instituto da desapropriação: uma agenda de termas para reflexão. In. Op. Cit., p. 33.

${ }^{258}$ ÁVILA, Humberto. Repensando o "Princípio da Supremacia do Interesse Público sobre 
tiona-se se a referida fluidez, plasticidade da noção não ofereceria risco aos direitos fundamentais, porquanto a defesa de um triunfo a priori e em qualquer caso do interesse público importaria na assunção de uma postura arbitrária, de permanente choque com o valor fundamental da segurança jurídica.

Contudo, deve-se atentar para o fato de que os conceitos jurídicos indeterminados possuem uma densidade mínima a partir da qual se concretizam. ${ }^{259}$ Ainda que não constituam noção pronta e acabada, seu conteúdo possui conexão, referibilidade com a normatividade constitucional enquanto produto de um consenso fundamental ${ }^{260}$. Assim, no horizonte de um Estado Democrático de Direito, eventuais prerrogativas conferidas à Administração Pública devem ser tomadas no seu caráter instrumental, na medida em que constituem autênticos deveres-poderes ${ }^{261}$ conferidos ao administrador na consecução do interesse público, da finalidade legal (aqui compreendida na perspectiva alargada, enquanto vinculação ao ordenamento jurídico como um todo).

Sem embargo, cabe também realçar que a indeterminação de um conceito não pode servir de entrave a sua aplicação, notadamente porque a abstração ao nível do texto legal não produz necessariamente discricionariedade no nível fático, empírico ${ }^{262}$. Distintos são os níveis de indeterminação a depender da hipótese. Assim, "quando se considera o interesse público como sinônimo de bem comum, ou seja, como fim do Estado, a indeterminação atinge o seu grau mais elevado. Essa indeterminação diminui quando o princípio é considerado nos diferentes ramos do direito". ${ }^{263}$

Exemplificando: dentre os fundamentos constitucionais da desapropriação ordinária encontra-se o interesse social, noção indubitavelmente plástica e permeada de fluidez. Contudo, não resta dúvida que no caso do projeto do Porto do Rio, um dos macroprojetos imobiliários sediados no Rio de Janeiro, o interesse social a justificar eventuais desapropriações apenas restará configurado se for resultado de um projeto urbanístico público, inclusivo dos cidadãos cariocas, a justificar e legitimar o dispên-

o Particular". In: Interesses públicos versus interesses privados: desconstruindo o princípio de supremacia do interesse público. (Org. Daniel Sarmento). Rio de Janeiro: Lumen Juris, 2010, p. 191.

${ }^{259}$ MELLO, Celso Antônio bandeira de. Discricionariedade e controle jurisdicional. São Paulo: Malheiros, 2000, p. 29.

${ }^{260}$ OLIVEIRA, Fábio Corrêa Souza de. Por uma teoria dos princípios: o princípio constitucional da razoabilidade. Rio de Janeiro: Lumen Juris, 2007, pp. 172-173.

${ }^{261}$ MELLO, Celso Antônio Bandeira de. Curso de Direito Administrativo. Op. Cit., p. 29.

${ }^{262}$ Idem. Discricionariedade e controle jurisdicional. Op. Cit., pp. 28-32.

${ }^{263}$ DI PIETRO, Maria Sylvia Zanella. O princípio da supremacia do interesse público: sobrevivência diante dos ideais do neoliberalismo. In: Supremacia do interesse público e outros temas relevantes do direito administrativo (Coords. Maria Sylvia Zanella Di Pietro e Carlos Vinícius Alves Ribeiro). São Paulo: Atlas, 2010. Op. Cit., p. 98. 
dio de vultosos recursos públicos ${ }^{264}$.

Outrossim, necessário reconhecer a artificialidade de uma contraposição acentuada entre o interesse público e o interesse privado, especialmente porque o interesse público pode também estar na satisfação de determinados interesses pri$\operatorname{vados}^{265}$, ou seja, não há antagonismo entre as noções, o interesse público não é "um interesse a se stante, autônomo, desvinculado dos interesses de cada uma das partes que compõe o todo". ${ }^{266}$ Conforme explica Celso Antônio Bandeira de Mello, o que pode haver é um interesse singular, um interesse individual do sujeito que pode, eventualmente, contrapor-se ao interesse do todo, ao interesse da coletividade entendido como aquele "igualmente pessoal destas mesmas pessoas ou grupos, mas que comparecem enquanto partícipes de uma coletividade maior na qual estão inseridos". ${ }^{267}$

Vale dizer: o interesse público, seja ele qual for, não terá sempre supremacia em detrimento do particular. Somente a primazia in concreto de um interesse público legal, constitucional, entendido como o interesse da sociedade capaz de albergar os direitos fundamentais (inclusive os direitos sociais), é que merece amparo.

Isto é, diante da suposição que milita em favor dos atos administrativos, presume-se legítima a atuação estatal até eventual prova em contrário. A regra é presumir que aquilo que a Administração afirma ser interesse público realmente seja e que, como regra, predomine sobre o interesse privado. Notadamente frente à percepção de que o interesse público é noção correlacionada à ideia de solidariedade, validada também nos direitos individuais.

\section{A questão da motivação}

Para a compreensão da temática da motivação dos atos administrativos faz-se imprescindível abordar o conceito de "motivo". Conforme leciona Maria Sylvia Di Pietro, o motivo se define como o "pressuposto de direito e de fato que serve de fundamento ao ato administrativo" 268 . Enquanto o pressuposto de direito se refere a determinado dispositivo legal como fundamento de determinado ato, o pressuposto de fato corresponde ao conjunto de circunstâncias fáticas que levaram a Administra-

\footnotetext{
${ }^{264}$ Acerca do assunto, consultar: http://www.soniarabello.com.br/porto-do-rio-sera-mesmo -uma-maravilha-3. Acessado em: 26 de outubro de 2013.

${ }^{265}$ BARROSO, Luís Roberto. Prefácio: o Estado contemporâneo, os direitos fundamentais e a redefinição da supremacia do interesse público. In: Interesses públicos versus interesses privados: desconstruindo o princípio de supremacia do interesse público. (Org. Daniel Sarmento). Rio de Janeiro: Lumen Juris, 2010.

${ }^{266}$ MELLO, Celso Antônio bandeira de. A noção jurídica de "interesse público". Op. Cit., p. 181.

${ }^{267}$ Ibid., p. 183.

${ }^{268}$ DI PIETRO, Maria Sylvia Zanella. Direito Administrativo. Op. Cit., p. 218.
} 
ção a praticar esse ato ${ }^{269}$. Conquanto o motivo e a motivação dos atos administrativos estejam intimamente relacionados, ambos os conceitos não podem, em nenhuma circunstância, ser confundidos.

A motivação dos atos administrativos contempla a explicitação dos motivos que culminaram com a prática do ato. Trata-se de um assunto que ainda suscita grande discussão no âmbito do Direito Administrativo. Ao passo que alguns autores entendem que a motivação é necessária apenas quando a lei expressamente a exi$\mathrm{ge}^{270}$, outros autores entendem a motivação como um requisito de todo ato administrativo, sendo sempre obrigatória para a validade do ato ${ }^{271}$.

Por se tratar da exposição dos motivos, a motivação, segundo Maria Sylvia Di Pietro, "não pode limitar-se a indicar a norma legal em que se fundamenta o ato" ${ }^{272}$. A motivação deve ser compreendida, ainda, como princípio geral do Direito Administrativo, de forma a exigir que a Administração Pública indique, em todos os seus atos, os fundamentos de fato e de direito de todas as suas decisões ${ }^{273}$.

A exigência da justificativa de direito e de fato torna-se extremamente razoável quando se leva em consideração que o cidadão, bem como o Poder Judiciário, devem ter mecanismos que os permitam analisar e controlar a legalidade dos atos praticados pela Administração Pública, até mesmo para que se possa destacar se houve desvio de finalidade na atuação administrativa. Nesse sentido, é indispensável que a motivação contenha todos os elementos que permitam o controle da legalidade do ato. Isso porque a motivação é o mecanismo que permite a verificação da consonância ou não do ato com os princípios a que se submete a Administração Pública ${ }^{274}$.

Quando se está diante de uma motivação insuficiente, fica evidentemente prejudicado o controle cidadão. E é justamente por essa razão que a temática da motivação ganha especial relevância dentro da problemática da desapropriação e dos decretos expropriatórios - ato pelo qual a Administração efetiva a desapropriação.

Assim, a motivação se torna uma ferramenta essencial para o controle dos

269 Idem. Discricionariedade administrativa na Constituição de 1988. São Paulo: Atlas, 2012, p. 136.

${ }^{270}$ Em CARVAlHO FilHO, José dos Santos. Manual de Direito Administrativo. Op. Cit., pp. 106-108: o autor defende a posição que os atos administrativos precisam apresentar a motivação apenas quando a lei expressamente a exige.

${ }^{271} \mathrm{Na}$ linha dos autores que defendem a obrigatoriedade da motivação em todos os atos administrativos podemos citar Celso Antonio Bandeira de Mello e Maria Sylvia Di Pietro.

${ }^{272}$ Na mesma linha, Celso Antônio Bandeira de Mello, que vai além, dispondo que na motivação devem estar abrangidas: "(a) a regra de Direito habilitante; (b) os fatos em que o agente se estribou para decidir; e (c) a enunciação da pertinência lógica entre os fatos ocorridos e o ato praticado", em: MELLO, Celso Antônio bandeira de. Curso de Direito Administrativo. São Paulo: Malheiros, 2009, pp. 394-395.

${ }^{273}$ DI PIETRO, Maria Sylvia Zanella. Direito Administrativo. Op. Cit., p. 77.

${ }^{274}$ Idem. Discricionariedade administrativa na Constituição de 1988. Op. Cit., p. 136. 
atos administrativos pelos cidadãos e pelo próprio Poder Judiciário. Fica evidente que não há outra forma para que o expropriado se certifique de que foi atendido o princípio da proporcionalidade que não o conhecimento do motivo pelo qual ele está sendo desapropriado. Sem conhecer esse motivo, como poderá verificar se ele é legítimo e se está sendo cumprido na prática?

Apesar de a Constituição de 1988 não prever diretamente em seu texto legal a exigência da motivação dos atos administrativos, não é mais possível pensar em atos administrativos que não contenham motivação, principalmente quando se leva em consideração a irradiação constitucional para todos os demais ramos do direito. A motivação torna-se um elemento essencial para possibilitar o diálogo entre o Estado e os cidadãos. A motivação deve ser entendida, inclusive, como uma das conquistas mais importantes em termos de garantia de legalidade dos atos administrativos ${ }^{275}$.

\section{DECRETOS EXPROPRIATÓRIOS}

Ato inicial que possui o condão de materializar a desapropriação, o decreto expropriatório se apresenta como veículo legalmente ${ }^{276}$ necessário à publicidade do instituto. Estes atos administrativos competem originalmente ${ }^{277}$ aos chefes dos Poderes Executivos (presidente, governadores e prefeitos), enquanto representantes do fim socialmente pretendido no interesse público, devendo ser expedidos por meio dos Diários Oficiais no âmbito de suas respectivas esferas de atuação.

Com o fito de se verificar a hipótese inicial, realizou-se pesquisa empírica direcionada aos decretos expropriatórios. Porém, houve a necessidade de serem traçados critérios delimitadores, diante da amplitude do universo em questão, quais sejam: (i) temporal - sendo analisados todos os decretos expropriatórios compreendidos entre os anos de $2010^{278}$ e 2013 ; e; (ii) espacial - delimitou-se a pesquisa aos decretos publicados no Diário Oficial do Município do Rio de Janeiro.

Diante da proposta empreendida, lançou-se mão de uma pesquisa eminentemente qualitativa para atestar a profundidade da motivação fornecida nos atos em apreço. Desta monta, foram traçadas duas outras categorias, decretos expropriatórios

\footnotetext{
${ }^{275}$ Ibidem, p. 136.

276 Tal divulgação se dá em cumprimento à redação do seguinte artigo da Lei Geral das Desapropriações (Decreto Lei n. 3.365/41): “Art. 2º Mediante declaração de utilidade pública, todos os bens poderão ser desapropriados pela União, pelos Estados, Municípios, Distrito Federal e Territórios".

277 Quanto ao tema, apesar de não se dar por meio de decreto, uma vez que este é próprio tão somente dos Entes políticos, cabe destacar que "Podem promover a desapropriação, isto é, efetivar a desapropriação, ou seja, praticar atos concretos para efetuá-la (depois de existente uma declaração de utilidade pública expedida pelos que têm poder para submeter um bem à força expropriatória), além da União, Estado, Municípios, Distrito Federal e Territórios, as autarquias, os estabelecimentos de caráter público em geral ou que exerçam funções delegadas do Poder Público e os concessionários de serviço, quando autorizados por lei ou contrato." MELlO, Celso Antônio Bandeira de. Curso de Direito Administrativo, Op. Cit., p. 768. ${ }^{278}$ Vide nota 2.
} 
(i) sem justificativa - mencionando meramente letra de lei ou processo administrativo; e (ii) com justificativa material - elencando certos aspectos minimamente justificadores da drástica intervenção Estatal.

Foram encontrados um total de 205 Decretos Municipais expropriatórios, nos quais observou-se que um número ínfimo de 5 , correspondente a $2,44 \%$ do total, possui algum tipo de justificativa material, enquanto o restante $(97,56 \%)$ traz apenas a justificativa legal ou referência aos processos administrativos relacionados.

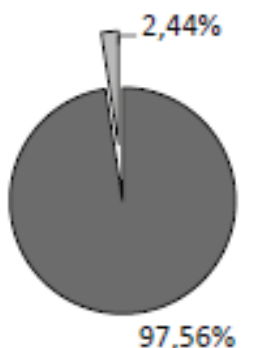

Sem Justificativa (expressamente na lei ou em processo administrativo)

$\square$ Justificativa Material

Figura 1: Gráfico da análise da justificativa apresentada nos Decretos Expropriatórios

Importa destacar que mesmo os decretos expropriatórios classificados como de justificativa material apresentam motivação rasa e insuficiente, de forma que não resta evidenciada a adequada qualificação do interesse público que poderia legitimar a atuação estatal na desapropriação. Veja-se:

DECRETO Nº. 33363, DE 18 DE JANEIRO DE 2011.

Declara de utilidade pública, para fins de desapropriação, os imóveis citados.

O PREFEITO DA CIDADE DO RIO DE JANEIRO, no uso de suas atribuições legais, tendo em vista o disposto nos artigos $5 .^{\circ}$, alínea "I", e o $6 .^{\circ}$ do Decreto-Lei n. ${ }^{\circ} 3.365$, de 21 de junho de 1941 , com a redação que lhe deu a Lei Federal n. 9.785 , de 29 de janeiro de 1999, e

CONSIDERANDO que a Lei Complementar $n^{\circ} 108$ de 25 de novembro de 2010 autorizou a constituição de Operação Interligada na área do Sambódromo com o objetivo de viabilizar a implantaçäo de projetos e intervenções previstos para o Sambódromo, visando preparar a Cidade do Rio de Janeiro para acolher os Jogos Olímpicos e Paraolímpicos de 2016, especialmente no entomo imediato dos equipamentos que serão utilizados como instalações esportivas;

CONSIDERANDO que a realização destas obras constitui a oportunidade de criar um legado positivo para os bairros de Catumbi e Cidade Nova, viabilizando melhorias urbanísticas e requalificação da área de entorno do equipamento, e complementando seu projeto original, o que proporcionará seu melhor aproveitamento em eventos já tradicionais de valor turístico e cultural da Cidade;

CONSIDERANDO a oportunidade de expansão do Sambódromo para a implantação de sistema viário de circulação local, de forma a contribuir para a valorização do patrimônio cultural tombado;
CONSIDERANDO a necessidade de expansão das dependências do Sambódromo, na Avenida Marquês de Sapucaí, para adequar-se à realização dos Jogos Olímpicos de 2016 no Rio de Janeiro;

CONSIDERANDO que a complementação do projeto original do Sambódromo, proporcionará seu melhor aproveitamento em eventos já tradicionais de valor turístico e cultural para a Cidade do Rio de Janeiro, valorizando a Avenida dos Desfiles e sel entorno, bem como contribuindo para a integração da Passarela do Samba com seu entorno; e

CONSIDERANDO que os bairros da Cidade Nova e Catumbi necessitam de investimentos públicos que viabilizem a requalificação do espaço urbano, trazendo melhorias para o entorno dos demais imóveis de interesse histórico destes bairros,

DECRETA:

Art. 1. ${ }^{\circ}$ Ficam declarados de utilidade pública, para fins de desapropriação os imóveis, abaixo relacionados, necessários a implantação de sistema viário e equipamentos públicos:

Rua Tomaz Rabelo

Desapropriação Total

n. ${ }^{\circ}$ (s) $12 ; 18 ; 20$ e 22

- Travessa Pedregais

Desapropriação Total

n. ${ }^{\circ}$ (s) $9 ; 11 ; 13$ e 15

Art. $2 .^{\circ}$ Este decreto entra em vigor na data de sua publicação. Rio de Janeiro, 18 de janeiro de $2011 ; 446^{\circ}$ ano da fundação da Cidade. EDUARDO PAES

Figura 2: Exemplo de decreto expropriatório que traz uma justificativa material ${ }^{279}$

${ }^{279}$ Diário Oficial do Município do Rio de Janeiro - Ano XXIV, nº 205, página 3 - Quarta- 
A despeito da indicação da finalidade do ato de desapropriação, isto é, o Poder Público apresenta os resultados pretendidos com as obras a serem realizadas, não há qualquer exposição acerca dos caminhos trilhados para identificar o interesse público da coletividade em tais alterações urbanísticas.

Como se percebe, há oportunidade e espaço legal ${ }^{280}$ para que o Poder Público aprofunde mais e melhor a motivação quando da expedição de seus atos, no intuito de atribuir-lhes legitimidade e representatividade. Todavia, os dados indicam claramente que o mesmo se abstém de tal conduta ao restringir a raríssimos casos a exposição do que o próprio autodenomina como considerações.

Em face de todo o exposto, observa-se que a problemática apresentada neste artigo se insere no contexto do aspecto material do decreto expropriatório, pois se observam diversas inconsistências no que tange à divulgação de seus motivos. Temos que, na prática, a Administração se utiliza deste ato de maneira meramente justificadora do contexto legal da desapropriação, não atentando ao seu conteúdo em si.

Desta forma, a falta de uma motivação consistente se torna mais que evidente, ou melhor, o que se observa na maioria dos casos é a manifesta ausência da divulgação dos motivos da desapropriação. Dificultando, dessa forma, tanto um amplo debate na sociedade quanto ao tema assim como a própria defesa do administrado, que corre o risco de perder sua propriedade sem um entendimento adequado do procedimento.

Razão pela qual os decretos, como veículos de suma importância à publicidade do ato em voga, devem ser repensados à luz de uma lógica que, de fato, coadune com o Estado Democrático de Direito brasileiro.

\section{DisCRICIONARIEDAde E MÉRITO}

Ao averiguar os aspectos concernentes ao interesse público nos deparamos com algumas questões de suma importância para a temática da desapropriação, dentre elas as relacionadas ao mérito e à discricionariedade. Tais conceitos revelam-se fundamentais quando da discussão sobre os requisitos da desapropriação, ou seja, se, de fato, a desapropriação atende aos seus fundamentos constitucionais de interesse social e utilidade pública.

Nesta linha, o denominado mérito consiste em uma qualidade típica do ato administrativo e diz respeito a sua conveniência, utilidade, oportunidade, adequação

feira, dia 19 de janeiro de 2011. Disponível em <http://doweb.rio.rj.gov.br/>. Acessado em diversas datas entre os meses de abril e outubro de 2013.

${ }^{280}$ Dentre a qual, destacamos o exemplo taxativo presente no Art. 50, inciso I da Lei que regula o processo administrativo no âmbito da Administração Pública Federal (Lei n. 9.784 de 29/01/1999), in verbis: "Art. 50. Os atos administrativos deverão ser motivados, com indicação dos fatos e dos fundamentos jurídicos, quando: I - neguem, limitem ou afetem direitos ou interesses; (...)". 
ao interesse público e aos princípios que regem à Administração Pública. Trata-se de expressão da escolha do objeto e da valoração de seus motivos quando a Administração Pública se vê autorizada a deliberar sobre a conveniência e a oportunidade do ato administrativo ${ }^{281}$.

Há discricionariedade quando o legislador deixa à Administração Pública a possibilidade de escolher entre duas ou mais opções válidas e adequadas para a solução do caso concreto, baseado em razões de mérito ${ }^{282}$. Trata-se da margem de liberdade concedida pela lei ao administrador, visto que é impossível prever todas as hipóteses que a prática administrativa demanda, ficando a cargo da Administração Pública determinar a melhor solução dentro dos parâmetros legais.

A problemática envolvendo a noção de discricionariedade está em aferir quando o administrador age dentro dos limites legais (discricionariedade) ou quando ele ultrapassa essas fronteiras e incide em arbitrariedade. Isto porque só há discricionariedade se houver conformidade com a lei e com o ordenamento jurídico. Havendo discrepância, trata-se de ato arbitrário e não discricionário. Estes primeiros seriam passíveis de reforma pelo Judiciário, uma vez que afrontam a ordem jurídica vigente.

Com efeito, trata-se de questão extremamente complexa, pois a posição doutrinária defendida durante muitos anos ${ }^{283}$ e arraigada na jurisprudência é de que seria vedado ao Judiciário controlar o mérito, porquanto aspecto político do ato administrativo. No entanto, não se pode usar o mérito como impedimento à atuação típica do Poder Judiciário, qual seja, apreciar os aspectos de legalidade do ato e verificar se ele foi praticado dentro dos limites impostos à discricionariedade ${ }^{284}$.

Mais recentemente, a doutrina e a jurisprudência têm modificado, paulatinamente, este entendimento, e permitido que o Judiciário examine o mérito administrativo sem substituir a vontade do administrador pela sua própria. O que tem ocorrido é uma redução do que se entendia por mérito administrativo, pois aspectos antes vedados ao controle judicial são hoje vistos como aspectos de legalidade em seu sentido amplo. ${ }^{285}$

Trata-se de entendimento lógico, pois sem a aferição do Judiciário não há

\footnotetext{
${ }^{281}$ MEIRELLES, Hely Lopes. Direito Administrativo Brasileiro. Op. Cit., p. 121.

${ }^{282}$ MELLO, Celso Antônio bandeira de. Discricionariedade e controle jurisdicional. Op. Cit., p. 48.

${ }^{283}$ Na lição de Carlos Roberto de Siqueira Castro: "no Brasil vigora uma exagerada resistência ao controle judicial do mérito dos atos do Poder Público, isto é, daquela zona de discricionariedade em que o agente do Estado desfruta de autonomia para decidir no tocante à oportunidade e conveniência de sua própria atuação". CASTRO, Carlos Roberto de Siqueira. O devido processo legal e a razoabilidade das leis na nova Constituição do Brasil. Rio de Janeiro: Forense, 1989, pp. 177-178.

${ }^{284}$ DI PIETRO, Maria Sylvia Zanella. Discricionariedade Administrativa na Constituição de 1988. Op. Cit., pp. 127-137.

${ }^{285}$ Ibidem.
} 
como se identificar se um ato é discricionário ou arbitrário. A confirmação da qualidade do ato administrativo, ou seja, se sua característica é de conformidade com o ordenamento ou "não, somente se dá a posteriori, uma vez que já foi aferido o juízo sobre aquele ato. Para que se conheça de algo e se saiba de suas propriedades, é preciso examiná-lo". ${ }^{286}$ Desta forma, é forçoso reconhecer que se trata de etapa posterior a um exame de mérito da medida ${ }^{287}$.

O que se deve defender, portanto, não é uma postura ativista do Judiciário ou a substituição dos preceitos de interesse público do administrador pelos preceitos do julgador, mas sim garantir que a discricionariedade da Administração seja controlada, seja praticada dentro de limites, sendo o Poder Judiciário o fiscal de sua atuação. Assim, o que não pode ocorrer é a invalidação de mérito que foi pronunciado ou exercido regularmente, dentro dos parâmetros legais. Isso porque, a apreciação e exame do juízo de conveniência e oportunidade é um pressuposto para que se declare eventuais vícios.

Simplesmente enunciar que a discricionariedade não pode ser objeto de controle pelo Poder Judiciário é chancelar a perspectiva de que mesmo os atos administrativos arbitrários devem ser tidos como válidos. Perspectiva esta que não encontra mais amparo no sistema constitucional vigente.

\section{Pesquisa jurisprudencial}

Conforme mencionado anteriormente, com a formulação das hipóteses de trabalho, realizou-se pesquisa jurisprudencial para (i) verificar a atuação do Poder Judiciário na análise do mérito da desapropriação, isto é, se os julgadores discutem o interesse público em desapropriar (utilidade pública e interesse social); (ii) examinar se o desapropriado/jurisdicionado possui mecanismos eficazes para questionar os fundamentos da desapropriação; e (iii) a partir da pesquisa qualitativa, traçar o comportamento do Poder Judiciário de maneira a determinar uma previsibilidade em futuros julgamentos, notadamente, quando as ações envolvendo os megaeventos chegarem aos tribunais superiores.

Em acesso à base de dados virtual ${ }^{288}$ desses Tribunais Superiores, durante todo o mês de Setembro de 2013, foram verificadas as decisões relacionadas ao objeto da pesquisa. O marco temporal abrange todas as decisões disponíveis, sendo a mais antiga de 1944 e a mais recente de 2013.

Inicialmente, foi lançada somente a expressão "desapropriação", obten-

${ }^{286}$ OLIVEIRA, Fábio Corrêa Souza de. Morte \& Vida da Constituição Dirigente. Rio de Janeiro: Lumen Juris, 2010, p. 362.

${ }^{287}$ Ibidem.

${ }^{288}$ Disponível em: http://www.stf.jus.br/portal/jurisprudencia/pesquisarJurisprudencia.asp e http://www.stj.jus.br/SCON/, respectivamente. Acessado em diversas datas, entre os meses de abril e outubro de 2013. 
do-se como resultado 3.057 decisões no STF e 6.206 no STJ, perfazendo um total de 9.263 decisões que tratam do assunto. A partir desta primeira aproximação, refinou-se a pesquisa com palavras-chave relacionadas ao objeto do trabalho, que são: mérito; discricionariedade; desvio de finalidade; conveniência e oportunidade; e tredestinação.

Lançando-se a expressão "desapropriação" em conjunto com cada uma das palavras-chave obteve-se um resultado filtrado ${ }^{289}$. Com esse refinamento da pesquisa, houve um processo de seleção das decisões nas quais o Poder Judiciário realizou cognição ampla do processo. Para tanto, efetuou-se a análise de cada decisão na íntegra, quando possível, uma vez que foi encontrada dificuldade com relação ao acesso aos dados no STJ, que não fornecia todas as peças processuais, justificandose por serem processos físicos e não terem sido digitalizados e disponibilizados na base de dados virtual. No âmbito do STF, foi possível, além da análise da ementa, a verificação da íntegra de todas as decisões do Tribunal.

Muitas ações não chegaram a ter o mérito analisado, tendo os Tribunais Superiores, na esmagadora maioria das decisões, conhecido do recurso, mas negado provimento $^{290} \mathrm{sob}$ o fundamento de impossibilidade de análise fático-probatório ${ }^{291}$. Com o refinamento utilizando as palavras-chave, o número se reduziu para 94 ações, o que representa aproximadamente $1 \%$ do total, como demonstra o gráfico abaixo:

\footnotetext{
${ }^{289}$ Dá-se um exemplo: na combinação da expressão "desapropriação" com a palavra-chave "desvio de finalidade" obtém-se uma ementa de decisão livremente escolhida para a exemplificação: "1. Resolve-se em perdas e danos o conflito surgido com o desvio de finalidade do bem expropriado. 2. Evidenciado o desvio de bem que, destinado à construção de uma quadra esportiva, veio a ser cedido para construção de "Loja Maçônica". Infringência ao art. 1.150 do Código Civil. 3. REsp conhecido e provido" (STJ, REsp 43651/SP, Segunda Turma, Rel. Min. Eliana Calmon, DJ 05.06.2000.

290 "a admissibilidade dos recursos subordina-se ao preenchimento de certos requisitos ou pressupostos, antecedendo, lógica e cronologicamente, a análise do mérito do recurso (...) este exame preliminar sobre o cabimento do recurso denomina-se juízo de admissibilidade, transposto o qual, em sentido favorável ao recorrente, passará o órgão recursal ao juízo de mérito do recurso" in KOZIKOSKI, Sandro Marcelo. Manual dos Recursos Cíveis: teoria geral e recursos em espécie. Curitiba: Juruá Editora, 2008, p. 57.
}

${ }^{291}$ Súmula 279 do STF: "Para simples reexame de prova não cabe recurso extraordinário"; e Súmula 7 do STJ: "A pretensão de simples reexame de prova não enseja recurso especial". 


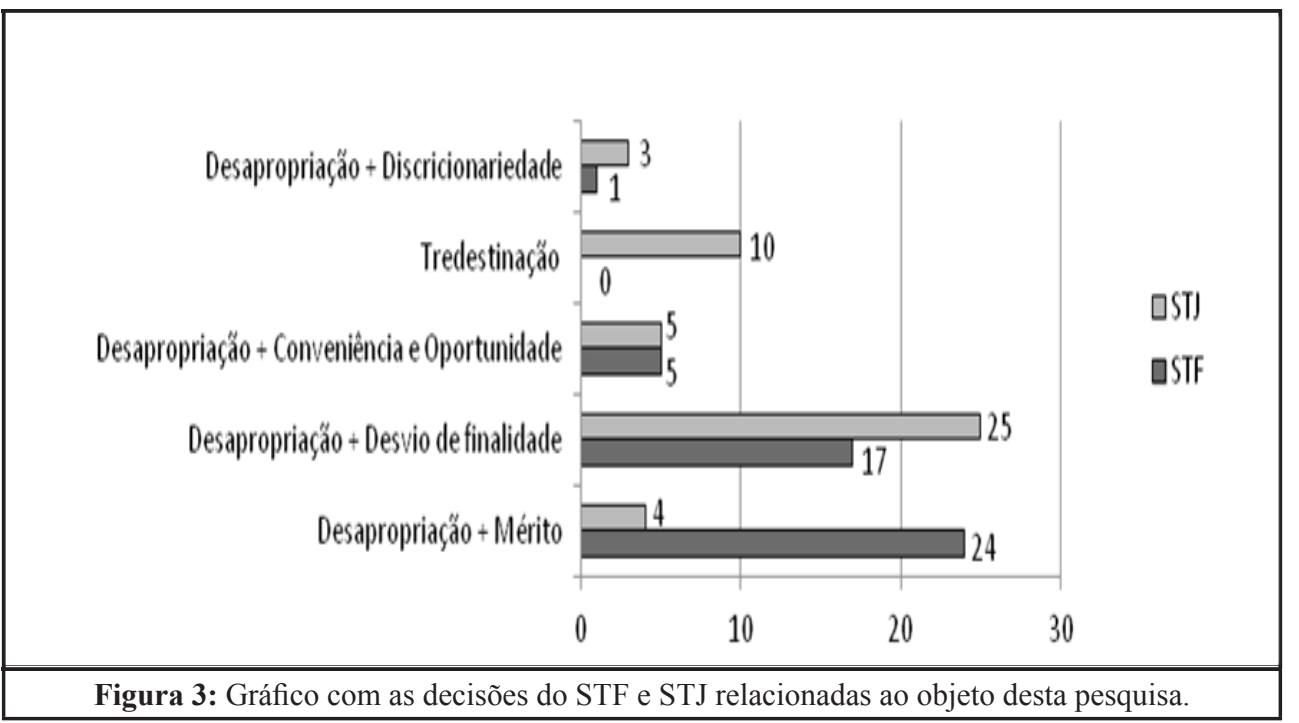

Da análise efetuada dessas 94 ações que guardam relação com o objeto da pesquisa, somente em 11 (onze) ações o Poder Judiciário examinou o mérito, isto é, discutiu a questão do interesse público, o motivo pelo qual a desapropriação ocorreu. Esse número reduzido de ações comprova parte da hipótese desta pesquisa, qual seja, a de postura autocontida do Poder Judiciário, demonstrando certo grau de conservadorismo, não admitindo, em geral, a verificação do mérito administrativo.

A outra parte da hipótese da pesquisa também foi comprovada, uma vez que dessas 11 (onze) ações, somente 4 (quatro) conseguiram paralisar a desapropriação (REsp 1225 292, MS 4298, MS 19961 e MS 24110), permanecendo o bem com seus proprietários, enquanto que as demais (REsp 43651, RMS 18703, REsp 816251, REsp 1014161, REsp 623511, REsp 124474 e RE 86046) foram convertidas em perdas e danos, devido ao longo tempo que a ação tramitou na Justiça, fazendo com que o bem fosse incorporado ao patrimônio do Ente Público expropriante ${ }^{293}$.

292 "EMENTA: I- Conquanto ao judiciário seja defeso incursionar sobre a oportunidade e conveniência de desapropriação, pode e deve ele escandir os elementos que indicam a legitimidade do ato bem como a finalidade pois, ai, reside o freio a discricionariedade por isso. Que a declaração de utilidade pública terá de indicar, precisamente, o fim a que se destina a expropriação. II - tendo em conta o interesse público, é vedado a administração desapropriar para construção de imóveis sem especificar a perseguição do interesse público, e dizer, a finalidade. III- se a finalidade referida no decreto expropriatório e fraudada, desmerece-se, por si própria, a desapropriação. IV-recurso provido e remessa dos autos ao Pretório Excelso".

${ }^{293}$ Artigo 35 do Decreto-Lei n. 3.336/1941: “Os bens expropriados, uma vez incorporados à Fazenda Pública, não podem ser objeto de reivindicação, ainda que fundada em nulidade do processo de desapropriação. Qualquer ação, julgada procedente, resolver-se-á em perdas 
Comprova-se que o desapropriado/jurisdicionado não possui mecanismos eficazes para questionar os fundamentos da desapropriação.

Por fim, com essa análise jurisprudencial é possível traçar um perfil de ação do Poder Judiciário que possivelmente prevalecerá quando as ações de desapropriação relacionadas aos megaeventos chegarem aos Tribunais Superiores. A comprovação de que os desapropriados, se não conseguirem reaver seus bens devido ao longo tempo de tramitação dos processos (conforme fundamentação supra), também não poderão contar com a esperança em ver o mérito da desapropriação discutido pelos julgadores.

\section{Conclusão}

Tomando por base o estudo prático, viu-se ratificada a primeira parte da hipótese, qual seja, que o Poder Executivo (1) não realiza a exposição dos motivos da desapropriação de forma aceitável. Isto é, não descreve quais as razões e os critérios para a supressão do direito individual em prol do interesse público envolvido na desapropriação. Com a pesquisa realizada sobre os decretos expropriatórios, percebe-se que a falta da motivação é ainda mais latente do que se imaginava. Do total de decretos que dão a destinação ao bem, somente $2,44 \%$ destes realmente forneceram alguma motivação, conforme entendimento supra.

Não bastasse a constatação deste fato, há a confirmação de que (2) a análise judicial foi estritamente legalista, traduzindo uma posição autocontida, posto que, em muitos casos, os julgadores entenderam que o mérito do juízo discricionário contido na desapropriação compete privativamente ao administrador. Foi necessário a verificação de um flagrante despropósito do ato, um abuso de poder "evidente"294 para um efetivo controle sobre a atuação do Poder Executivo.

A despeito de sua missão institucional, que é a de preservar possíveis violações às garantias fundamentais previstas na Constituição, percebe-se que o foco remanesce na inviolabilidade do princípio da separação entre os poderes ${ }^{295}$. Repare

e danos".

${ }^{294}$ A expressão, "abuso de poder gritante", foi utilizada pelo Min. Antônio Pádua Ribeiro, relator do Mandado de Segurança n. 4298 do Distrito Federal de caráter preventivo, julgado em 28 de agosto de 1996. A constatação foi a de que “(...) No caso, a ameaça de violência ou abuso de poder era tão gritante que, tomando conhecimento desta impetração, a digna autoridade impetrada, nas suas informações, reconheceu expressamente o direito liquido e certo de os impetrantes não terem os seus imóveis expropriados”. Foi rejeitada a preliminar de ilegitimidade passiva ad causam, ou seja, ilegitimidade da autoridade coatora, para que no exame do mérito fosse concedida a medida de segurança. Em voto vencido, o Min. Adhemar Maciel defendeu que a preliminar de mérito deveria ser acolhida. Fonte da pesquisa: $h t t p: / /$ www.stj.jus.br/portal_stj/publicacao/engine.wsp. Acessado em: 29.10.2013.

${ }^{295}$ CRFB/1988: “Art. 2. São Poderes da União, independentes e harmônicos entre si, o Legislativo, o Executivo e o Judiciário”. 
que a ideia aqui defendida, não é a de que o Poder Judiciário deve se substituir no juízo político da Administração acerca da conveniência e oportunidade. Pelo contrário, entende-se que este juízo é legitimamente garantido ao administrador na sua função precípua.

Neste prisma, especialmente no tocante ao interesse público, é premente que se estabeleçam critérios de qualificação, mormente quanto a garantir a justaposição dos interesses convergentes. O que se nota é a aplicação incisiva de um decreto de 1941, anacrônico, que já não mais corresponde às expectativas do Direito Administrativo contemporâneo. Desta forma, faz-se mister interpretá-lo à luz da Constituição, que expandiu o rol de direitos e garantias fundamentais.

Se por um lado a realização da pesquisa leva a demonstração de um Poder Judiciário conservador diante da discussão acerca do interesse público, por outro, revelou um dado alarmante: o de que os indivíduos ainda (3) não possuem mecanismos eficazes para questionar o interesse público envolvido na desapropriação.

A comprovação desta terceira hipótese corrobora para um quadro de afastamento entre o interesse do Estado e o interesse individual, pois propicia que certos abusos sejam cometidos por parte do ente público contra os direitos individuais. A prerrogativa de império conferida à Administração para agir em nome da coletividade pode ser maquinada de forma imprudente, sem a devida cautela. É o que ocorre com a realização dos megaeventos.

Mas, além disto, a falta de remédio judicial cabível leva a impossibilidade de o administrado ver assegurado um direito, o direito de ação. Do ponto de vista social e político, isto pode levar, por parte dos indivíduos, a uma descrença nas instituições do Estado, promotor do bem comum e do interesse coletivo.

Sem embargo da discussão inicial acerca da função social e do direito de propriedade, a solução precisa e a posição defendida é a de que o Judiciário, realizando sua função, deve verificar as razões que o administrador se utilizou para determinar o interesse público na desapropriação. A partir daí passaria a anular os atos viciados, sejam eles contestados por meio de ação coletiva, por exemplo, Ação Civil Pública; por meio de ação individual, neste caso, o mandado de segurança; ou ainda na própria ação de desapropriação.

Além disso, não basta que os atos eivados de vício sejam anulados. É indispensável também que o administrador cumpra com o dever de motivação dos seus atos e que os indivíduos afetados sejam ouvidos e participem do processo de construção do interesse público, através de assembleias ou audiências públicas. Assim, aliando-se aos conceitos de interesse público, mérito e discricionariedade, poder-se -ia, finalmente, coibir abusos e arbitrariedades. 


\section{REFERÊNCIAS}

ÁVILA, Humberto. Repensando o "Princípio da Supremacia do Interesse Público sobre o Particular." In: Interesses públicos versus interesses privados: desconstruindo o princípio de supremacia do interesse público. (Org. Daniel Sarmento). Rio de Janeiro: Lumen Juris, 2010.

BARROSO, Luís Roberto. Prefácio: o Estado contemporâneo, os direitos fundamentais e a redefinição da supremacia do interesse público. In: Interesses públicos versus interesses privados: desconstruindo o princípio de supremacia do interesse público. (Org. Daniel Sarmento). Rio de Janeiro: Lumen Juris, 2010.

CASTRO, Carlos Roberto de Siqueira. O devido processo legal e a razoabilidade das leis na nova Constituição do Brasil. Rio de Janeiro: Forense, 1989.

Diário Oficial do Município do Rio de Janeiro. Disponível em: http://doweb.rio. rj.gov.br/. Acessado em diversas datas entre os meses de abril e outubro de 2013.

DI PIETRO, Maria Sylvia Zanella. Discricionariedade Administrativa na Constituição de 1988. 3. ed. São Paulo: Atlas, 2012.

. Direito Administrativo. São Paulo: Atlas, 2013.

O princípio da supremacia do interesse público: sobrevivência diante dos ideais do neoliberalismo. In: Supremacia do interesse público e outros temas relevantes do direito administrativo (Coords. Maria Sylvia Zanella Di Pietro e Carlos Vinícius Alves Ribeiro). São Paulo: Atlas, 2010.

FONSECA, Maria Guadalupe Piragibe. Iniciação à pesquisa no Direito: pelos caminhos do conhecimento e da invenção. Rio de Janeiro: Elsevier, 2009.

KOZIKOSKI, Sandro Marcelo. Manual dos Recursos Cíveis: teoria geral e recursos em espécie. $4^{\mathrm{a}}$ ed. rev. e atual. Curitiba: Juruá Editora, 2008.

MEIRELLES, Hely Lopes. Direito Administrativo Brasileiro. São Paulo, Malheiros, 2010.

MELLO, Celso Antônio bandeira de. A noção jurídica de "interesse público". In: Grandes Temas de Direito Administrativo (Celso Antônio Bandeira de Mello). São Paulo: Malheiros, 2009.

. Curso de Direito Administrativo. São Paulo: Malheiros, 2010.

. Discricionariedade e controle jurisdicional. São Paulo: Malheiros,

2000.

MOREIRA NETO, Diogo de Figueiredo. Curso de Direito Administrativo: Parte Introdutória, Parte Geral e Parte Especial. Rio de Janeiro: Forense, 2009. 
OLIVEIRA, Fábio Corrêa Souza de. Morte \& Vida da Constituição Dirigente. 2. ed. Rio de Janeiro: Lumen Juris, 2010.

. Por uma teoria dos princípios: o princípio constitucional da razoabilidade. 2. ed. Rio de Janeiro: Lumen Juris, 2007.

Organização das Nações Unidas. "Report of the Special Rapporteur on adequate housing as a component of the right to an adequate standard of living, and on the right to non-discrimination in this context”. Disponível em: http://www.ohchr.org/ Documents/ Issues/Housing/SecurityTenure/InfoNote2013-Tenure-Eng-31jan2013. pdf. Acessado em: 01.08.2013.

RABELLO, Sonia. Porto do Rio: será mesmo uma "Maravilha”?. 2011. Disponível em: http://www.soniarabello.com.br/porto-do-rio-sera-mesmo-uma-maravilha-3/. Acessado em: 26.10.2013.

(Footnotes)

${ }^{1}$ Diário Oficial do Município do Rio de Janeiro - Ano XXIV, n 205, página 3 Quarta-feira, dia 19 de janeiro de 2011. Disponível em http://doweb.rio.rj.gov.br/. Acessado em diversas datas entre os meses de abril e outubro de 2013. 